\title{
IDENTIFIKASI TELUR CACING NEMATODA USUS PADA ANAK-ANAK YANG TINGGAL DI DAERAH KANAL KELAPA TIGA MAKASSAR
}

\author{
Ulkia Multiani Asri ${ }^{1)}$, Mujahidah Basarang ${ }^{1)}$, Muh. Rifo Rianto ${ }^{1)}$ \\ 1) Prodi D3 Teknologi Laboratorium Medis Politeknik Kesehatan Muhammadiyah Makassar \\ Alamat korespondensi: ulkiamultianiasri@gmail.com
}

\begin{abstract}
Abstrak
Nematoda usus merupakan cacing parasit yang hidup dalam usus manusia yang dapat menyebabkan helminthiasis/kecacingan. Penyakit helminthiasis ditularkan melalui tanah, baik melalui kontak langsung maupun dengan perantara seperti makanan. Tanah maupun makanan yang terkontaminasi telur cacing dapat menyebar ke anak-anak saat mereka bermain dan tidak mencuci tangan sebelum makan. . Penelitian ini bertujuan untuk mengetahui Identifikasi telur cacing nematoda usus pada anakanak yang tinggal di daerah Kanal Kelapa Tiga Kota Makassar. Jenis penelitian ini adalah observasi laboratorik dengan teknik pengambilan sampel secara accidental sampling dengan besaran sampel sebanyak 10 sampel feses yang kemudian diperiksa dengan menggunakan metode sedimentasi. Berdasarkan hasil penelitian yang telah dilakukan dari 10 sampel feses yang diperiksa 5 diantaranya positif terdapat nematoda usus dengan jenis cacing yang ditemukan adalah telur Ascaris lumbricoides, Trichuris trichiura, larva rabditiform necator americanus dan telur infertil dan 5 sampel lainnya negatif. Sehingga dapat di simpulkan bahwa terdapat infeksi kecacingan pada beberapa anak-anak yang tinggal di daerah Kanal Kelapa Tiga Kota Makassar.
\end{abstract}

Kata kunci: Nematoda Usus, Anak-anak, Feses, Sedimentasi

\section{PENDAHULUAN}

Nematoda usus adalah kelompok parasit yang dapat menyebabkan kecacingan (Helminthiasis). Penyakit kecacingan merupakan salah satu penyakit yang kurang mendapat perhatian tetapi masih banyak terjadi di masyarakat. Penyakit ini disebabkan oleh infeksi cacing kelompok Soil Transmitted Helminth (STH) yaitu kelompok cacing yang siklus hidupnya melalui tanah (Basarang, et al., 2018).

Nematoda merupakan salah satu jenis cacing parasit yang paling sering ditemukan pada tubuh manusia. Nematoda yang hidup dalam usus manusia disebut dengan nematoda usus. Penyakit infeksi parasit nematoda usus menyebabkan masalah kualitas hidup seperti yang diungkapkan oleh Widjaya (2001), infeksi ini telah menyebabkan manusia kehilangan karbohidrat, protein, dan darah yang cukup besar, menurunkan kemampuan fisik dan ketajaman fikiran anak-anak, menurunkan produktivitas kerja orang dewasa dan mengurangi daya tahan tubuh sehingga lebih rentan terhadap serangan penyakit lainnya. (Denai W' 'et al'. 2012).

Prevalensi nematoda usus yang sering menyebabkan infeksi cacing adalah "Soil Transmitted Helminthes (STH)" yang merupakan infeksi cacing usus yang ditularkan melalui tanah yang terkontaminasi melalui kontak langsung dengan telur parasit atau larva yang berada di tanah. Cacing yang tergolong dalam kelompok STH adalah Ascaris lumbricoides, Necator americanus, Ancylostoma duodenale,Trichuris trichiura, Strongyloides strercoralis dan yang tergolong kelompok Non STH adalah Enterobius vermicularis dan Trichinella spiralis (Inge S, et. al., 2008).

Adapun masalah kesehatan yang disebabkan oleh kelompok STH seperti 
anemia, obstruksi saluran empedu, radang pankreas, usus buntu, alergi, dan diare, penurunan fungsi kognitif (kecerdasan), kurang gizi, gangguan pertumbuhan, dan radangparu-paru (Agustina 2015).

Berdasarkan data dari WorldOrganization (WHO) pada tahun 2012 lebih dari 1.5 miliar orang atau $24 \%$ dari populasi dunia terinfeksi Soil Transmitted Helminths (STH). Di Indonesia sendiri prevalensi kecacingan pada tahun 2012 menunjukkan angka diatas $20 \%$ dengan prevalensi tertinggi mencapai $76,67 \%$, infeksi kecacingan ini mengalami penurunan dimana pada tahun 2011 dilakukan survei diberbagai provinsi. Prevalensi di Sumatera mencapai $78 \%$, Kalimantan 79\%, Sulawesi $88 \%$, Nusa Tenggara Barat $92 \%$ dan Jawa barat 90\% (Andi dan Azriful, 2016).

Sulawesi selatan adalah salah satu provinsi di Indonesia yang menunjukkan angka prevalensi helminthiasis. Berdasarkan data dari Dinas Kesehatan Provinsi sulawesi selatan bahwa penderita kecacingan di Sulawesi Selatan masih terbilang banyak yaitu pada tahun 2011 (11.884 kasus), 2012 (9.476 kasus), 2013 (12.949 kasus), 2014 (13.375 kasus). Selanjutnya berdasarkan data dari Dinas Kesehatan Kabupaten/Kota mengalami peningkatan dari tahun 2013 (3.226 kasus), 2014 (3.266 kasus), 2015 (3.270 kasus). Adapun daerah tertinggi kasus kecacingan di Kota Makassar tepatnya berada di daerah kepulauan yaitu di Pulau Kodingareng Lompo berada di kelurahan Kodingareng, kecamatan Ujung Tanah Kota Makassar, Berdasarkan data yang diperoleh dari Puskesmas Kodingareng Lompo penderita kecacingan di wilayah tersebut pada tahun 2013 (364 kasus), 2014 (778 kasus) (Amaliah dan Azriful 2016).

Tingginya angka prevalensi cacingan pada umumnya terjadi karena kurangnya pengetahuan bagi masyarakat dan keadaan pekerjaan masyarakat yang masih sering kontak langsung dengan tanah, mempengaruhi dan mendukung penyebaran. Salah satu kelompok masyarakat sangat beresiko terinfeksi telur cacing adalah anakanak. Kontaminasi langsung bisa terjadi kepada anak-anak pada saat mereka bermain tanah kemudian tidak mencuci tangan sebelum makan.

Tinggi prevalensi kecacingan Non STH dapat dipakai sebagai penduga barat atau ringannya derajat infeksi. Infeksi ringan memiliki jumlah infeksi 50-500, infeksi sedang memiliki 500-2000 dan infeksi berat memiliki jumlah lebih dari 2000 derajat keparahan infeksi tergantung jumlah cacing yang menginfeksi. Penurunan berat badan akan terjadi pada infeksi 300 ekor dewasa.

Pencemaran tanah merupakan penyebab terjadinya transmisi telur cacing dari tanah kepada manusia melalui tangan atau kuku yang mengandung telur cacing lalu masuk ke mulut bersama makanan. Tinggi rendahnya frekuensi tingkat kecacingan berhubungan dengan kebersihan diri dan sanitasi lingkungan yang menjadi sumber infeksi. Penularan cacingan lebih banyak terjadi pada daerah kumuh yang tidak memenuhi syarat kesehatan seperti sanitasi lingkungan yang ditunjang dengan kepadatan penduduk. Faktor penunjang yang menyebabkan seseorang terkena cacingan antara lain keadaan alam serta iklim, sosial ekonomi, pendidikan, kepadatan penduduk, serta masih berkembangnnya kebiasaan yang kurang baik (Natadisastra, 2009).

\section{METODE PENELITIAN}

\section{Alat dan Bahan}

Peralatan yang digunakan dalam proses penelitian ini antara lain lidi, objek glass, cover glass, mikroskop, tabung reaksi, pengaduk, sentrifuge, pipet tetes, beaker glass, tabung sentrifuge, cawan porselin, sendok tanduk, neraca analitik.

Bahan yang digunakan yaitu larutan eosin, feses, aquades. 


\section{Pengumpulan Sampel}

Membagikan pot sampel kepada anak-anak yang akan diambil fesesnya. Feses yang sudah terkumpul segera di periksa dengan menggunakan metode sedimentasi.

\section{Pemeriksaan Telur Cacing}

Emulsi tinja (feses) dibuat didalam beaker glass volume $100 \mathrm{ml}$, dengan cara tinja diambil sebanyak 2 gram dan ditambahkan aquades sampai tanda $100 \mathrm{ml}$, lalu diaduk hingga tercampur dengan baik, emulsi tinja di pipet ke dalam tabung reaksi sebanyak $1 / 3$ tabung dari permukaan tabung, pemusingan dilakukan dengan menggunakan alat sentrifuge pada kecepatan 3000 rpm selama 5 menit, kemudian larutan supernatant dibuang dan ditambahkan lagi aquades diaduk hingga tercampur, pemusingan dilakukan sampai supernatannya jernih, jika supernatannya telah jernih maka supernatan langsung dibuang dan endapan yang tersisa dipipet lalu diletakkan di atas objek gelas yang bersih dan kering, zat pewarna ditambahkan yaitu menggunakan larutan eosin dan diemulsikan di atas objek glass bersama dengan tinja, setelah homogen, ditutup dengan cover glass dan dilihat di bawah mikroskop pada pembesaran lemah (objektif 10x dan okuler 10x) (Dewi Kamalasari. 2015).

Interpretasi Hasil

Positif (+): Terdapat telur cacing Soil Transmitted (STH) dan Non STH

Negatif (-): Tidak terdapat telur cacing Soil Transmitted (STH) dan Non STH

\section{HASIL DAN PEMBAHASAN}

Berdasarkan hasil penelitian yang dilakukan di Laboratorium Parasitologi Politeknik Kesehatan Muhammadiyah Makassar, dari 10 sampel feses yang diperiksa menggunakan metode sedimentasi didapatkan hasil pada tabel 1 berikut.
Tabel 1. Hasil Pemeriksaan Telur cacing Nematoda Usus pada feses anakanak di daerah Kanal Kelapa Tiga Kota makassar

\begin{tabular}{|c|c|c|c|}
\hline $\begin{array}{c}\text { Kode } \\
\text { sampel }\end{array}$ & $\begin{array}{c}\text { Usia } \\
\text { (Tahun) }\end{array}$ & Hasil & Keterangan \\
\hline A & 5 & Positif & $\begin{array}{l}\text { Telur Ascaris } \\
\text { lumbricoides }\end{array}$ \\
\hline B & 6 & Positif & $\begin{array}{l}\text { Telur Infertil } \\
\text { Larva }\end{array}$ \\
\hline $\mathrm{C}$ & 7 & Positif & $\begin{array}{l}\text { Rabditiform } \\
\text { Necator } \\
\text { americanus }\end{array}$ \\
\hline $\mathrm{D}$ & 8 & Positif & $\begin{array}{l}\text { Telur Ascaris } \\
\text { lumbricoides }\end{array}$ \\
\hline E & 8 & Negatif & - \\
\hline F & 9 & Negatif & - \\
\hline $\mathrm{G}$ & 10 & Negatif & - \\
\hline $\mathrm{H}$ & 10 & Positif & $\begin{array}{l}\text { Telur Ascaris } \\
\text { lumbricoides }\end{array}$ \\
\hline I & 11 & Negatif & - \\
\hline $\mathrm{J}$ & 12 & Negatif & - \\
\hline
\end{tabular}

Dari hasil penelitian diketahui bahwa dari beberapa sampel feses anak-anak yang diambil di Kecamatan Kelapa Tiga Kota Makassar sebanyak 10 sampel, yang diperiksa dengan menggunakan metode sedimentasi terdapat 5 sampel yang positif $(50 \%)$ dan 5 sampel negatif (50\%). Stadium pertumbuhan nematoda usus yang ditemukan adalah telur Ascaris lumbricoides,Trichuris trichiura, larva rabditiform necator americanus dan telur Ascaris lumbricoides yang tidak dibuahi atau biasa disebut dengan telur infertil, telur infertil merupakan telur yang tidak mengalami pembuahan dan perkembangan embrio pada saat penetasan sehingga tidak terbentuk sempurna. Ciri-ciri dari telur infertil ini yaitu bentuknya lebih lonjong, ukuran lebih besar, berwarna kuning kecoklatan dan tidak mengandung embrio di dalamnya (Rosdiana S. 2009).

Penularan helminthiasis ditularkan melalui tanah atau biasa disebut dengan 
"Soil Transmitted Helminths" (STH). Salah satu jenis cacing yang tergolong dalam kelompok STH ini yaitu Ascaris lumbricoides, Trichuris trichiura, dan larva rabditiform necator americanus, telur Ascaris lumbricoides ditularkan melalui tanah dan yang terkontaminasi oleh telur cacing ini seperti, makanan dan debu. Infeksi yang disebabkan oleh Ascaris lumbricoides dapat menimbulkan kematian, baik dikarenakan larva maupun cacing dewasanya. Larva cacing Ascaris lumbricoides mengakibatkan rasa mual, mulas, diare, gata-gatal, kejang-kejang, meningitis (radang selaput otak), demam, apatis, rasa mengantuk, kelumpuhan dan dapat menimbulkan hepatitis, askariasis, pneumonia (Koes, I. 2009).

Pasien yang mendapat infeksi kronis Trichuris menunjukkan tanda- tanda seperti anemia, tinja yang bercampur butir-butir darah, sakit perut, kekurangan berat badan dan prolaps rectal yang berisi cacing pada mukosa rektum (Koes I. 2013).

Larva filariform aktif menembus kulit luar tuan rumah melalui folikel-folikel rambut, pori-pori atau kulit yang rusak. Larva masuk ke saluran vena menuju ke jantung kanan, dari sana masuk ke saluran paru-paru, menuju jaringan paru-paru sampai ke alveoli. dari situ mereka naik ke bronkus dan trakea, tertelan dan masuk ke usus. Peredaran larva dalam sirkulasi darah dan bermigrasi ke paru-paru berlangsung selama satu minggu. Selama periode ini mereka bertukar kulit untuk ketiga kalinya. Setelah berganti kulit empat kali dalam jangka waktu 13 hari mereka menjadi dewasa. Yang betina bertelur 5-6 minggu setelah infeksi. Infeksi per oral jarang terjadi, tapi larva dapat masuk ke dalam badan melalui air minum atau makanan yang terkontaminasi (Koes I. 2013).

Pada hasil penelitian ini menunjukkan bahwa tingkat infeksi kecacingan pada beberapa petugas sampah di Kecamatan
Rappocini Kota Makassar tinggi, ini memperlihatkan bahwa anak-anak tidak dapat menjaga higiene pribadi karena kebiasaan bermain di tanah dan tidak mencuci tangan sebelum makan. Tetapi dengan menjaga hygiene pribadi seperti mencuci tangan sehabis bermain dan sebelum makan dapat menghilangkan telur cacing yang terkontaminasi sehingga dapat mencegah masuknya larva aktif yang ada ditanah melalui kulit dan memperhatikan kebersihan sanitasi lingkungan, dengan perilaku hidup bersih dan sehat dapat menurunkan tingkat terjadinya infeksi cacing.

Adapun hasil observasi yang telah dilakukan pada seluruh anak-anak yang menjadi sampel dalam penelitian ini menyebutkan bahwa sepulang dari sekolah dia bermain dan memulung sehingga dia terkontamisasi oleh tanah dan tidak memperhatikan untuk mencuci tangan sebelum makan dan ada yang beberapa pernah mengkonsumsi obat cacing walaupun tidak teratur bahkan ada juga anak-anak yang sudah di operasi karena didalam ususnya terdapat cacing. Dan dari umur mereka yaitu sekitar 5-12 tahun, usia yang belum paham dan mengerti pentingnya menjaga kebersihan dan kesehatan, sehingga tingkat kerentanan masuknya suatu penyakit lebih tinggi. Lama bermain tanah juga dapat mempengaruhi terjadinya infeksi cacing, semakin lama mereka dalam bermain tanah maka semakin sering melakukan kontaminasi langsung dengan tanah yang memungkinkan terjadinya infeksi cacing dan pada saat pemeriksaan telur cacing dilakukan, telur dapat teridentifikasi karena sudah terjadi siklus hidup yang berulang dalam tubuh hospes. Berbeda dengan anakanak yang jarang bermain di tanah walaupun sudah ada telur cacing yang tertelan masuk ke dalam tubuh meraka, pada saat diperiksa telur cacing tersebut belum teridentifikasi atau tidak didapatkan karena siklus hidup 
telur cacing jika tertelan bersama makanan membutuhkan waktu yang lama yaitu sekitar 2-3 bulan untuk menjadi dewasa kemudian bertelur dan berkembang biak.

Faridan (2013) mengatakan bahwa penyakit cacingan paling banyak terjadi pada anak usia sekolah dasar 5-12 tahun. Hal itu disebabkan anak pada usia tersebut sering melakukan kontak dengan tanah saat bermain. DEPKES RI Makassar (2006) menyatakan bahwa anak usia sekolah dasar merupakan golongan tertinggi terinfeksi cacing yang penularannya melalui tanah.

Pada dasarnya infeksi kecacingan bisa dicegah dan disembuhkan dengan cara menjaga higine pribadi, meminum obat cacing secara teratur, memperhatikan kebersihan lingkungan sekitar dan menjaga pola hidup bersih dan sehat. Seperti yang diungkapkan oleh Undang Ruhimat dan Herdiyana (2014) bahwa infeksi cacing bisa dikurangi dan dihindari dengan memperhatikan kebersihan, baik kebersihan diri sendiri, keluarga dan lingkungan. Karena dengan memperhatikan kebersihan adalah salah satu cara untuk mencegah terjadinya penyakit kecacingan.

\section{KESIMPULAN DAN SARAN}

Berdasarkan hasil penelitian yang telah dilakukan dari 10 sampel yang diperiksa 5 diantaranya positif nematoda usus dengan jenis cacing yang ditemukan adalah telur Ascaris lumbricoides, Trichuris trichiura, larva Rabditiform necator americanus dan Ascaris lumbricoides yang tidak dibuahi dan 5 sampel lainnya negatif.

Dari penelitian ini diharapkan kepada masyarakat khususnya anak-anak agar selalu menjaga pola hidup yang bersih dan sehat, agar tidak mudah terinfeksi nematoda usus. Selain itu diharapkan kepada pemerintah dinas kebersihan agar lebih memperhatikan lingkungan agar tingkat infeksi kecacingan berkurang.

\section{DAFTAR PUSTAKA}

Agustina Dwi I.V. 2015. Identifikasi Telur Cacing Nematoda Usus Pada Lalapan Daun Selada (Lactuca sativa L.) yang dijual di Kelurahan Madyopuro Kota Malang. [Skripsi]. Malang: Akademi Analis Kesehatan Malang.

Amaliah, ATR, Azriful. 2016. Distribusi Spasial Kasus Kecacingan (Ascaris lumbricoides) Terhadap Personal Higiene Anak Balita di Pulau Kodingareng Kecematan Ujung Tanah Kota Makassar. ISSN: 24431141 Vol. 2(2): 75-78

Basarang, M., Azis, N. N., Rasyid, N. Q., Rianto, M. R. dan Rasiyanto, E. 2018. Penyuluhan Kecacingan dan Pemeriksaan Telur Cacing pada Murid Kelas 1 SD Inpres Borongkaramasa Kecamatan Palangga Kabupaten Gowa. Seminar Nasional Hasil Pengabdian Kepada Masyarakat: 323-324.

Denay W 'et al'. 2012. Telur Parasit Nematoda Usus pada Pemukiman Kurang Sehat di Kota Pekanbaru. Jurnal Kesehatan Komunitas. Vol. 1, No. 4, Hal: 188-189.

Departemen Kesehatan. 2009. Kategori Umur Menurut Depkes RI. Jurnal Pendidikan Kesehatan Rekreasi. Vol. 1, Hal. 44-46

Dewi Kamalasari. 2015. Pemeriksaan Telur Nematoda Usus pada Anak-Anak di sekitar Ratulangi Lorong 1 Makassar. Karya Tulis Ilmiah (KTI) tidak diterbitkan. Makassar: Program Diploma III Analis Kesehatan Akademi Analis Kesehatan Muhammadiyah Makassar.

Dinas Kesehatan Pemerintah Kota Makassar. 2015. Profil Kesehatan Kota Makassar Tahun 2015. Makassar. 
Koes Irianto. 2009. Parasitologi Berbagai Penyakit Yang Mempengaruhi Bandung: Kesehatan Manusia. CV. Yrama Widya:

Koes Irianto. 2013. Parasitologi Medis. Bandung: Alfabeta.

Natadisastra, D. dan Agoes, R. 2009. Parasitologi Kedokteran. Ditinjau dari Organ Tubuh yang di Serang. Jakarta: EGC.

Rosdiana Safar. 2009. Parasitologi Kedokteran Protozoologi Helmintologi Entomologi. Bandung: CV. Yrama Widya 